\title{
Publisher Correction: Maximizing Electrokinetic Energy Conversion via the Intersecting Asymptotes Method
}

\author{
Abraham Mansouri ${ }^{1}$ \& Larry Kostiuk ${ }^{2}$ \\ Correction to: Scientific Reports https://doi.org/10.1038/s41598-018-37360-6, published online 24 January 2019
}

This Article contains an error in Equation 1.

$$
I_{\text {streaming }}=2 \pi \int_{0}^{r}(r) \cdot \mathrm{u}(r) \cdot r \cdot d r
$$

should read:

$$
I_{\text {streaming }}=2 \pi \int_{0}^{r} \rho(r) \cdot \mathrm{u}(r) \cdot r \cdot d r
$$

(c) (i) Open Access This article is licensed under a Creative Commons Attribution 4.0 International License, which permits use, sharing, adaptation, distribution and reproduction in any medium or format, as long as you give appropriate credit to the original author(s) and the source, provide a link to the Creative Commons license, and indicate if changes were made. The images or other third party material in this article are included in the article's Creative Commons license, unless indicated otherwise in a credit line to the material. If material is not included in the article's Creative Commons license and your intended use is not permitted by statutory regulation or exceeds the permitted use, you will need to obtain permission directly from the copyright holder. To view a copy of this license, visit http://creativecommons.org/licenses/by/4.0/.

(c) The Author(s) 2019

${ }^{1}$ Department of Mechanical Engineering, Higher College of Technology, Dubai, 15825, UAE. ${ }^{2}$ Department of Mechanical Engineering, University of Alberta, Edmonton, Alberta, T2G 2G8, Canada. Correspondence and requests for materials should be addressed to A.M. (email: mansouri@ualberta.net) 